\title{
Susceptibility of Alabama argillacea and Chrysodeixis includens (Lepidoptera: Noctuidae) larvae to Beauveria bassiana associated with kaolin
}

\author{
J. S. Galdino ${ }^{a}$ (D) C. A. D. Silva ${ }^{a, b * ~(D), ~ J . ~ C . ~ Z a n u n c i o ~}{ }^{c}$ (D) and M. A. Castellanid ${ }^{\circ}$ \\ ${ }^{a}$ Universidade Estadual da Paraíba - UEPB, Programa de Pós-graduação em Ciências Agrárias, \\ Campina Grande, PB, Brasil

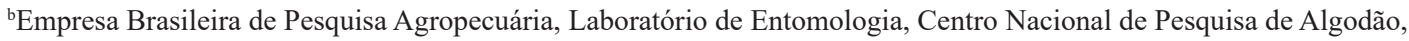 \\ Campina Grande, PB, Brasil \\ 'Universidade Federal de Viçosa - UFV, Departamento de Entomologia/BIOAGRO, Viçosa, MG, Brasil \\ ${ }^{d}$ Universidade Estadual do Sudoeste da Bahia - UESB, Departamento de Fitotecnia e Zootecnia, Vitória da \\ Conquista, BA, Brasil \\ *e-mail: carlos.domingues-silva@embrapa.br
}

Received: January 24, 2020 - Accepted: May 05, 2020 - Distributed: November 30, 2021

\begin{abstract}
The mortality of the Alabama argillacea and Chrysodeixis includens (Lepidoptera: Noctuidae) larvae caused by the kaolin inert powder and the entomopathogenic fungus Beauveria bassiana were determined under laboratory conditions. Using the caterpillar submersion method, the CG 138 B. bassiana isolate was more pathogenic to $A$. argillacea than the CG $70, \mathrm{GC} 82$, ESALQ 634, and ESALQ 645. All five tested isolates caused similar mortality of $C$. includens. The mortality of first-instar larvae of $A$. argillacea and $C$. includens by feeding on leaf-disc impregnated with B. bassiana (CG 138) and kaolin was also determined. Higher $A$. argillacea mortalities were observed in the B. bassiana (CG 138) treatments, regardless of the presence of kaolin. However, the activity of kaolin $+B$. bassiana (CG 138) against $C$. includens was higher than each ingredient alone, indicating an additive action against $C$. includes larvae. The mortality of $A$. argillacea and $C$. includens larvae treated with kaolin $+B$. bassiana (CG 138) was similar, and the A. argillacea mortality was higher than that of $C$. includens with kaolin and B. bassiana (GC 138) separated. The treatment kaolin + B. bassiana (CG 138) is promising for the simultaneous management of these two defoliator pests, mainly $A$. includes. In addition, the monophagous $A$. argillacea is more susceptible to both kaolin and B. bassiana (GC 138) than the polyphagous $C$. includens, suggesting that the nutritional ecology plays an important role in the susceptibility of these defoliator species to alternative insecticides.
\end{abstract}

Keywords: Associated use, cotton leafworm, Gossypium hirsutum, particle film, pathogenicity, soybean looper.

\section{Susceptibilidade de larvas de Alabama argillacea e Chrysodeixis includens (Lepidoptera: Noctuidae) a Beauveria bassiana associada com caulim}

\section{Resumo}

A mortalidade de larvas de Alabama argillacea e Chrysodeixis includens (Lepidoptera: Noctuidae), causada pelo pó inerte do caulim e pelo fungo entomopatogênico Beauveria bassiana, foi determinada em condições de laboratório. Usando o método de submersão da lagarta, o isolado CG 138 de B. bassiana foi mais patogênico para A. argillacea que os CG 70, GC 82, ESALQ 634 e ESALQ 645 desse fungo. Os cinco isolados testados causaram mortalidade semelhante de $C$. includens. A mortalidade de larvas de primeiro ínstar de $A$. argillacea e $C$. includens pelo método de alimentação em discos foliares impregnados com B. bassiana (CG 138) e caulim foi, também, determinada. A mortalidade de A. argillacea foi maior nos tratamentos com B. bassiana (CG 138), independentemente da presença do caulim. A atividade do caulim + B. bassiana (CG 138) contra C. includens foi maior que cada ingrediente isolado, indicando ação aditiva contra larvas desse Lepidoptera. A mortalidade de larvas de $A$. argillacea e $C$. includens, com caulim $+B$. bassiana (CG 138), foi semelhante e as de A. argillacea maiores que as de $C$. includens com caulim e B. bassiana (GC 138) isoladamente. O tratamento caulin + B. bassiana (CG 138) é promissor para o manejo simultâneo dessas duas pragas desfolhadoras, principalmente $A$. includens. Além disso, a monófaga, A. argilacea, é mais suscetível ao caulim e à $B$. bassiana (GC 138) que a polífaga, $C$. includens, sugerindo que a ecologia nutricional desempenha papel importante na suscetibilidade dessas espécies desfolhadoras a inseticidas alternativos.

Palavras chave: filme de partículas, Gossypium hirsutum, lagarta desfolhadora do algodão, lagarta desfolhadora da soja, patogenicidade, uso associado. 


\section{Introduction}

The cotton leafworm, Alabama argillacea (Hübner, 1818) and the soybean looper, Chrysodeixis includens (Walker, 1857) (Lepidoptera: Noctuidae) are cotton defoliator pests (Viana et al., 2014). These Lepidoptera pests have different specialization levels (monophagy and polyphagy) on cotton plants, and are controlled with synthetic chemical insecticides (Oliveira et al., 2010). The chemical control can cause environmental problems, including ecological unbalance; the development of insect and mite resistance to agrochemicals (to date, more than 500 resistant pests have been identified); outbreak of secondary pests; pest resurgence; harmful effects on humans, natural enemies of pests, fish and other non-target animals, in addition to persistent chemical residues in food, water and soil (Nascimento et al., 2016).

The use of kaolin particle film technology can improve the efficiency of insecticides to controlling cotton pests (Silva and Ramalho, 2013), including aphids, boll weevils, cotton leafworms, pink larvae and white flies, as well as the cotton bollworm complex and those of the genus Spodoptera (Neves et al., 2014; Gonçalves et al., 2015). The film of kaolin particles, sprayed on the surface of the host plants, creates a physical or mechanical barrier that can alter plant tissue taste and digestibility, reducing the feeding and survival of chewing insects (Gonçalves et al., 2015; Guedes et al., 2020). Kaolin may affect the insect cuticle permeability to water, a limiting factor for these organisms (Cook et al., 2008).

The entomopathogenic fungus Beauveria bassiana (Balsamo) Vuillemin is produced and used in Brazil to manage insect pests of many orders (César Filho et al., 2002; Sree and Varma, 2015). The wide genetic variability of this entomopathogen increases its importance in microbial insect control. The combined use of kaolin with $B$. bassiana may increase the effect of this entomopathogen in the control of $A$. argillacea and $C$. includens.

Inert dusts, such as mineral clays and silica powders, remove the epicuticular lipid layers of arthropods, causing excessive water losses through the cuticle, and death (Storm et al., 2016). These dusts are used in the management of pests of both plants during cultivation and also in stored products (El-Aziz, 2011; Silva and Ramalho, 2013). The combination of entomopathogenic fungi with inert kaolin powder needs to be studied against pests of cultivated plants and grains. Beauveria bassiana formulated with kaolin has been shown to be more effective against Oryzaephilus surinamensis (L.) (Coleoptera: Silvanidae) (Storm et al., 2016), Corcyra cephalonica
Stainton (Lepidoptera: Pyralidae) and Sitophilus oryzae (L.) (Coleoptera: Curculionidae) adults than with tapioca flour or unformulated (Samodra and Ibrahim, 2006a, b).

The objective of this research was to determine the susceptibility of the cotton leafworm, A. argillacea, and $C$. includes larvae to the entomopathogenic fungus $B$. bassiana combined with kaolin.

\section{Materials and Methods}

\subsection{Site of study}

The work was conducted at the Embrapa Algodão Entomology Laboratory, Campina Grande, Paraíba state, Brazil. Two experiments were performed. The first assessed the pathogenicity of $B$. bassiana isolates and the second evaluated the additive activity of kaolin combined with the most effective one.

\subsection{Insects and fungus isolates}

Alabama argillacea and $C$. includens specimens were obtained from the rearing colonies of this laboratory and fed on a semi-natural diet (Bestete et al., 2017).

The strains of the fungus B. bassiana, CG 70, CG 82 and CG 138, were obtained from the mycology collection of the Biological Control Laboratory of Embrapa Recursos Genéticos e Biotecnologia in Brasília, Federal District, Brazil, and the $\mathrm{Bb} 634$ and $\mathrm{Bb} 645$ strains from the ESALQ-USP mycology collection, Piracicaba, São Paulo, Brazil. These strains have been tested because they are highly virulent to lepidopteran larvae (César Filho et al., 2002) and are not commercially available. These strains were stored at $7^{\circ} \mathrm{C}$ in disposable Petri dishes with PDA (potato-dextrose-agar) and antibiotic (chloramphenicol) (PDA $+\mathrm{A})$ and Nujol oil until the beginning of the bioassays (Table 1).

\subsection{Isolate selection}

The pathogenic action of the $B$. bassiana isolates was determined in a completely randomized experimental design with six treatments (five isolates and one control) and 50 replications per isolate. The replications were performed by neonate larvae of each of the tested lepidopteran species. The strains were multiplied in Petri dishes containing PDA culture medium and incubated for 15 days (Silva, 2001) at $25^{\circ} \mathrm{C}$ under a 12 hours-photoperiod. The conidial suspensions of the $B$. bassiana strains were prepared with sterile solution of Tween $80^{\circledR}$ (SigmaAldrich, Saint Louis, MO, USA) at $0.1 \%$ as a surfactant. The control had only sterile water plus the surfactant. The first-instar larvae with one-day old of the A. argillacea or $C$. includens were submerged in the conidial suspension

Table 1. Identification of the strains, hosts and origin place of the entomopathogenic fungus Beauveria bassiana.

\begin{tabular}{ccc}
\hline Strains & Host & Origin Place \\
\hline CG070 & (Coleoptera: Curculionidae) & Brasília, DF \\
CG082 & Diabrotica speciosa (Coleoptera: Chysomelidae) & Tucumán, Argentina \\
CG138 & Cosmopolites sordidus (Coleoptera: Curculionidae) & Recife, PE \\
ESALQ 635 & Soil & Lavras, MG \\
ESALQ 645 & Soil & Alambari, SP \\
\hline
\end{tabular}


at the concentration of $10^{7}$ conidia $\mathrm{ml}^{-1}$ for five seconds. This concentration of $B$. bassiana conidia was used to facilitate the determination of the additive effect of kaolin. After drying on pre-sterilized filter paper, the larvae were transferred to plastic containers with cotton leaf disks, which were replaced daily until completion of the observations in a BOD-type climatic chamber at $25 \pm 1{ }^{\circ} \mathrm{C}, 60 \pm 10 \%$ relative humidity and photoperiod of 12 hours.

The percentage of insect mortality was evaluated during the first 10 days after pathogen application. The larvae that did not move after being touched with a brush bristle were considered dead. The dead larvae were immersed in $3 \%$ sodium hypochlorite solution for three seconds and then in distilled water and kept in a humid chamber for pathogen extrusion and confirmation of its pathogenicity.

\subsection{Susceptibility of larvae to kaolin and $\mathrm{B}$. bassiana}

The larvae susceptibility to the $B$. bassiana combined with kaolin was evaluated in a completely randomized design, with a $4 \times 2$ factorial scheme, represented by the cotton leaf disks immersed in distilled water (control) and suspensions of kaolin (Caulisa ${ }^{\circledR}$, Indústria de Caulim S.A., Campina Grande, Paraíba State, Brazil) at the concentration of 0.06 g. $\mathrm{ml}^{-1} ;$ B. bassiana at the concentration of $10^{7}$ conidia $\mathrm{ml}^{-1}$; and of the mixture of $0.06 \mathrm{~g}$ kaolin $+10^{7}$ conidia $\mathrm{ml}^{-1}$ of $B$. bassiana, each offered to first-instar $A$. argillace and $C$. includens larvae with fifty replications. The $B$. bassiana conidia suspension was composed by the isolate selected in the experiment of this fungus against A. argillacea or C. includens first-instar larvae. The kaolin dose was chosen based on previous studies against the cotton lepidopteran pests Spodoptera exigua (Lepidoptera: Noctuidae) (Showler, 2003) and A. argillacea (Lepidoptera: Noctuidae) (Gonçalves et al., 2015) and the apple leafworm Choristoneura rosacean (Harris) (Lepidoptera: Tortricidae) (Sackett et al., 2005).

Cotton plants of the cultivar BRS 286 were cultivated in an experimental area at Embrapa Algodão in the first half of 2018 and used in this study. The cotton leaves were collected from 40 day-old plants when they reached the stage of 12-16 leaves per plant and provided as food to first-instar larvae with one-day old of the two Lepidoptera species.

The newly hatched first-instar A. argillacea and $C$. includens larvae were individually transferred to cotton leaf discs kept in a plastic container $(3 \mathrm{~cm}$ high $\mathrm{x}$ $3 \mathrm{~cm}$ wide $\mathrm{x} 4 \mathrm{~cm}$ long) capped with a plastic plate. The cotton leaf discs were cut from the third expanded leaf counted from the apex of the plants. These were kept in a climatic chamber with the same conditions of the experiment of the "selection of isolates" until the end of the observations. Each replicate had one larvae per species of lepidopteran pest, fed with a cotton leaf disc and 50 replicates per treatment were used. The leaf discs were changed every two days until the end of the observations. The mortality of the larvae was evaluated daily for 10 days with the aid of a stereoscopic microscope.
The germination test of $B$. bassiana conidia was performed in both bioassays with the application of $50 \mathrm{~mL}$ of a suspension with $10^{7}$ conidia $\mathrm{mL}^{-1}$ per isolate in Petri dishes with the PDA culture medium. Observations were made 24 hours after starting the bioassay in a total of 500 conidia.

\section{Data analysis}

The $\mathrm{TL}_{50}$ (time to death of $50 \%$ of the first-instar of the cotton leafworm and the soybean looper) was calculated by the Probit method (Finney, 1964) with the data of percentage of mortality of the larvae in the pathogenicity bioassays. The means of mortality percentages were corrected (Abbott, 1925 ) and compared by the Student Newman Keuls test at $5 \%$ probability. Data from the mortality $(\%)$ versus $\mathrm{TL}_{50}$ variables were submitted to a correlation analysis. The percentage of larva mortality data in the susceptibility bioassay were corrected (Abbott, 1925) and submitted to variance analysis, and the means compared by the Student Newman Keuls test at $5 \%$ of probability. The statistical analyses were done with the System of Statistical and Genetic Analysis (Saeg) (Universidade Federal de Viçosa, Viçosa, Minas Gerais, Brazil).

\section{Results and Discussion}

The viability of the conidia of $B$. bassiana strains tested was higher than $95 \%$ in both bioassays.

\subsection{Selection of isolates}

The mortality of $A$. argillacea first-instar larvae in the pathogenicity bioassay 10 days after inoculation ranged from 51 to $93 \%$ for all strains tested $\left(\mathrm{F}_{4.25}=13.75 ; \mathrm{P}<0.001\right.$; Table 2$)$. A negative correlation between the $\mathrm{TL}_{50}$ values and the percentage of mortality of these larvae $(r=-0.99 ; \mathrm{P}<0.001)$ was found that is, the higher the percentage of $A$. argillacea neonate mortality, the shorter the time necessary to kill $50 \%$ of its population. The $B$. bassiana CG138 isolate was the most effective against $A$. argillacea first-instar larvae, followed by the ESALQ 634 and CG 82 and CG 70 and ESALQ 645 as the least effective (Table 2). Mortality of A. argillacea first-instar larvae with the GC 138 isolate was higher than that found $(81,74$ and $40 \%$ ) for third instar larvae of this species, with conidial suspension of B. bassiana strains UFRPE $645\left(10^{9}\right.$ conidia $\left.\mathrm{mL}^{-1}\right)$, UFRPE $604\left(10^{8}\right.$ conidia $\left.\mathrm{mL}^{-1}\right)$ and UFRPE $634\left(10^{7}\right.$ conidia $\left.\mathrm{mL}^{-1}\right)$, respectively (César Filho et al., 2002). These differences can be attributed to the inoculation and conidia concentration of this pathogen (Santoro et al., 2007), and to the larvae development stage (César Filho et al., 2002). Neonate larvae differ in scale, metabolism, digestive physiology, sensory modalities and intestinal microbiota from those of the late stages (Mason and Raffa, 2014; Despland, 2018). Furthermore, the neonate larvae are more selective to food and more sensitive to plant chemicals, possibly due to their more limited set of digestive enzymes (Hochuli, 2001). Therefore, they are often more vulnerable to plant compounds and pathogens that have a reduced effect on 
Table 2. Mortality (Mort.) and the $\mathrm{TL}_{50}$ (lethal time of 50\% of the insects) and confidence interval of Beauveria bassiana strains for Alabama argillacea and Chrysodeixis includens (Lepidoptera: Noctuidae).

\begin{tabular}{ccccccc}
\hline Pest insects & Strains & Mort $\mathbf{( \% )}$ & TL $_{\mathbf{5 0}}$ (Days) $^{\mathbf{2}}$ & $\boldsymbol{\chi}^{\mathbf{2}}$ & $P$ & Conf. Int. \\
\hline Alabama & CG 70 & $58 \mathrm{bc}$ & 5.02 & 39.66 & $<0.01$ & $(4.16 ; 6.10)$ \\
argillacea & CG 82 & $68 \mathrm{~b}$ & 3.76 & 36.01 & $<0.01$ & $(3.09 ; 4.44)$ \\
& CG 138 & $93 \mathrm{a}$ & 2.02 & 26.40 & $<0.01$ & $(1.68 ; 2.34)$ \\
& ESALQ 634 & $72 \mathrm{~b}$ & 3.72 & 34.53 & $<0.01$ & $(3.04 ; 4.40)$ \\
Chrysodeixis & ESALQ 645 & $51 \mathrm{c}$ & 5.94 & 42.73 & $<0.01$ & $(4.92 ; 7.44)$ \\
includes & CG 70 & $19 \mathrm{a}$ & 74.49 & 48.00 & $<0.01$ & $(25.36 ; 47.26)$ \\
& CG 82 & $23 \mathrm{a}$ & 14.09 & 61.54 & $<0.01$ & $(10.92 ; 22.82)$ \\
& CG 138 & 26 a & 11.82 & 54.01 & $<0.01$ & $(10.25 ; 15.19)$ \\
& ESALQ 634 & $13 \mathrm{a}$ & 26.25 & 53.09 & $<0.01$ & $(15.83 ; 99.06)$ \\
& ESALQ 645 & $18 \mathrm{a}$ & 19.62 & 54.70 & $<0.01$ & $(13.60 ; 44.99)$ \\
\hline
\end{tabular}

Mortality means followed by the same lower-case letter per insect-pest column do no differ by the Student Newman Keuls test at $5 \%$ probability. ${ }^{2}$ Calculated by the Probit method.

larvae of more advanced instars (Zalucki et al., 2002; Despland, 2018).

The mortality of first-instar $C$. includens larvae 10 days after inoculation ranged from 13 to $26 \%$ with all fungus strains $\left(\mathrm{F}_{4.25}=1.52 ; \mathrm{P}=0.22\right.$; Table 2$)$, with negative correlation between the values of $\mathrm{TL}_{50}$ and the mortality percentage $(\mathrm{r}=-0.30 ; \mathrm{P}=0.031)$. This indicates that there is no conclusive evidence of the association between $\mathrm{TL}_{50}$ values and the percentage mortality of $C$. includens. The low mortality of $C$. includens larvae is due to the low capacity of $B$. bassiana isolates to infect them. The insect cuticle is mainly composed of chitin with proteins, acting as a primary barrier against pathogens (Goettel et al., 2005; Xue et al., 2014). Beauveria bassiana produces chitinases and proteases to disintegrate the insect cuticle, but its efficacy depends on the spore size, conidia germination rate and metabolite production (Varea et al., 2012; Sree and Varma, 2015) and the composition of free fatty acids in the cuticle of the insects (Sree and Varma, 2015; Wronska et al., 2018). Long-chain fatty acids such as capric, undecanoic, stearic and oleic do not prevent $B$. bassiana conidia germination, but they may cause germ tube autolysis, preventing hyphae growth. Short-chain fatty acids such as butyric, valeric, caproic, heptanoic, caprylic, besides nanoparticulate can inhibit the germination tube of this fungus (Zhang et al., 2012).

\subsection{Susceptibility of larvae to kaolin and $\mathrm{B}$. bassiana}

The mortality of $A$. argillacea and $C$. includens larvae with distilled water, kaolin, B. bassiana (CG 138) and the kaolin + conidia suspension of $B$. bassiana (CG 138) showed a significant interaction between treatments and larvae species $\left(\mathrm{F}_{3.32}=24.08 ; \mathrm{P}<0.001\right.$; Table 3$)$, indicating that the larvae mortality is dependent on the species of insects and treatments. The B. bassiana CG 138 isolate caused the highest mortality of $A$. argillacea first-instar larvae. Mortality was higher with kaolin $+B$. bassiana (CG 138) (Table 3), followed by the treatment with kaolin alone. The similar mortality of $A$. argillacea larvae with $B$. bassiana $(\mathrm{CG} 138)$ and kaolin $+B$. bassiana $(\mathrm{CG} 138)$ indicate no additive or synergistic activity between this mineral and the fungus against this insect. The high mortality rates of kaolin-treated $A$. argillacea larvae corroborate results of lower survival and leaf consumption by first-instars of this pest on cotton plants treated with kaolin compared to non-treated ones (Gonçalves et al., 2015). The mortality of $A$. argillacea larvae was lower in the control.

The mortality of $C$. includens larvae was higher with kaolin $+B$. bassiana (CG 138), followed by those treated with $B$. bassiana (CG 138), and the lowest values were in the control and with kaolin alone $\left(\mathrm{F}_{3.32}=24,08\right.$; $\mathrm{P}<0.001$; Table 3 ). The higher mortality of $C$. includens larvae with kaolin $+B$. bassiana (GC 138) indicates an additive effect of this mineral and the fungus against this insect, as observed for the rice pest, $C$. cephalonica with B. bassiana and kaolin (Samodra and Ibrahim, 2006a). This is probably due to the hygroscopic kaolin action, reducing the digestibility and the protective function of the cuticle that lines the digestive tract of these larvae, making feeding difficult. This fact may have facilitated the pathogen's action and increasing the infection process (Eigenbrode et al., 2006; Gonçalves et al., 2015).

The mortality of $C$. includens larvae fed with cotton leaf discs treated with $B$. bassiana conidial suspension was higher (Table 3 ) than those with the conidial suspension in the first bioassay (Table 2). Therefore, inoculation methods may influence the results of selecting entomopathogenic fungi strains (Santoro et al., 2007).

The mortality of $A$. argillacea larvae was higher than those of $C$. includens with kaolin or B. bassiana (CG 138) alone, and was similar between these species in the treatments with kaolin $+B$. bassiana (CG 138) or distilled water (Table 3 ). The higher mortality of $A$. argillacea larvae fed with cotton leaf discs treated with $B$. bassiana conidial suspension may be related to differences in the morphology and physiology of these fungus strains and their hosts, similar to the previous bioassay. The higher mortality of $A$. argillacea treated with kaolin suggests a greater abrasive action of this rock powder on the digestive tract of $A$. argillacea compared to $C$. includens. Alabama 
Table 3. Mortality (\%) of Alabama argillacea and Chrysodeixis includens (Lepidoptera: Noctuidae) larvae fed cotton leaf disks impregnated with distilled water (control), kaolin $\left(0.06 \mathrm{~g} \mathrm{~mL}^{-1}\right)$, Beauveria bassiana $\left(10^{7}\right.$ conidia $\left.\mathrm{mL}^{-1}\right)$ and mixture of $0.06 \mathrm{~g}$ kaolin $+10^{7}$ conidia $\mathrm{mL}^{-1}$ of $B$. bassiana.

\begin{tabular}{ccc}
\hline Treatments & Alabama argillacea & Chrysodeixis includes \\
\hline Control (water) & $0.00 \pm 0.00 \mathrm{c} \mathrm{A}$ & $0.00 \pm 0.00 \mathrm{~d} \mathrm{~A}$ \\
Kaolin & $71.11 \pm 4.44 \mathrm{~b} \mathrm{~A}$ & $33.33 \pm 2.92 \mathrm{c} \mathrm{B}$ \\
Beauveria bassiana & $100.00 \pm 0.00 \mathrm{a} \mathrm{A}$ & $83.33 \pm 2.92 \mathrm{~b} \mathrm{~B}$ \\
Kaolin + Beauveria bassiana & $93.33 \pm 2.72 \mathrm{a} \mathrm{A}$ & $92.86 \pm 2.92 \mathrm{a} \mathrm{A}$ \\
\hline
\end{tabular}

Means followed by the same lower case letter per column and capital letter per line do not differ by the Student Newman Keuls test at $5 \%$ probability.

argillacea is a monophagous species and $C$. includens is polyphagous and, therefore, the structure of the midgut epithelium of these species may differ with their food habits and phylogenetic position (Bellanda and Zucoloto, 2009). Moreover, the polyphagia requires more complex physiological mechanisms to confront the host plant chemicals (Sarate et al., 2012), which may explain the mortality differences between these two insect species. Thus, the response of lepidopteran species appears to depend on the host specialization level, with a stronger response among monophagous species to variations in host quality compared to polyphagous species (Bestete et al., 2017).

The combination of kaolin $+B$. bassiana may increase the mortality of $C$. includens, but not that of $A$. argillacea. Applications of kaolin particles and the entomopathogenic fungus $B$. bassiana are compatible and can increase their efficiency in controlling some lepidopteran pest species. Difficulties in formulations of entomopathogenic fungi to compete with chemical insecticides are related to their usually narrower host range, especially when crop damage results from a pest complex (Wraight et al., 2010). Strains of entomopathogenic fungi are rarely virulent for all species infesting the crop (Hajek, 1997) and, economically, it is not feasible for producers to target each pest with a different product and/or isolate (Wraight et al., 2010). This suggests the possibility of formulating stabilized propagules of $B$. bassiana mixed with kaolin as a promising biological insecticide against defoliating larvae.

\section{Conclusions}

The kaolin + B. bassiana (CG 138) treatment showed an additive effect against the polyphagous $C$. includens larvae, but not against the monophagous A. argillacea larvae, which is equally susceptible to treatment with only B. bassiana and also to kaolin. This suggests that ecological nutrition plays an important role in the susceptibility of these defoliating species to alternative insecticides.

\section{Acknowledgements}

We thank the Brazilian institutions "Conselho Nacional de Desenvolvimento Científico e Tecnológico (CNPq)", "Coordenação de Aperfeiçoamento de Pessoal de Nível Superior- Brasil (CAPES)- Finance Code 001", "Fundação de Amparo à Pesquisa do Estado de Minas Gerais
(FAPEMIG)" and "Programa Cooperativo sobre Proteção Florestal/PROTEF do Instituto de Pesquisas e Estudos Florestais/IPEF" for financial support. David Michael Miller, a professional editor and proofreader and native English speaking, has reviewed and edited this article for structure, grammar, punctuation, spelling, word choice, and readability.

\section{References}

ABBOTT, W.S., 1925. A method of computing the effectiveness of an insecticide. Journal of Economic Entomology, vol. 18, no. 2 , pp. 265-266.

BELLANDA, H.C.H.B. and ZUCOLOTO, F.S., 2009. Lagartas desfolhadoras (Lepidoptera). In: A. PANIZZI and J.R.P. PARRA, eds. Bioecologia e nutrição de insetos: base para o manejo integrado de pragas. Brasília: Embrapa Informação Tecnológica, pp. 425-464.

BESTETE, L.R., TORRES, J.B., SILVA, R.B.B., SILVA-TORRES, C.S.A. and BASTOS, C.S., 2017. Development of cotton pests exhibiting different feeding strategy on water-stressed and kaolintreated cotton plants. Journal of Pest Science, vol. 90, 139-150.

CÉSAR FILHO, E., MARQUES, E.J. and BARROS, R., 2002. Selection of Metarhizium anisopliae (Metsch.) and Beauveria bassiana (Bals.) strains to control Alabama argillacea (Huebner) larvae. Scientia Agrícola, vol. 59, no. 3, pp. 457-462. http:// dx.doi.org/10.1590/S0103-90162002000300008.

COOK, D.A., WAKEFIELD, M.E. and BRYNING, G.P., 2008. The physical action of three diatomaceous earths against the cuticle of the flour mite Acarus siro L. (Acari: Acaridae). Pest Management Science, vol. 64, no. 2, pp. 141-146. http://dx.doi. org/10.1002/ps.1484. PMid:17972301.

DESPLAND, E., 2018. Effects of phenological synchronization on larvae early-instar survival under a changing climate. Canadian Journal of Forest Research, vol. 48, no. 3, pp. 247-254. http:// dx.doi.org/10.1139/cjfr-2016-0537.

EIGENBRODE, S.D., DING, H., NEUFELD, J. and DUETTING, P., 2006. Effects of hydrophilic and hydrophobic kaolin-based particle films on pea aphid (Homoptera: Aphididae) and its entomopathogen Pandora neoaphidis (Entomophthorales: Entomophthoraceae). Journal of Economic Entomology, vol. 99, no. 1, pp. 23-31. http://dx.doi.org/10.1093/ jee/99.1.23. PMid:16573319.

EL-AZIZ, S.E., 2011. Control strategies of stored products. Journal of Entomology, vol. 8, no. 2, pp. 101-122. http://dx.doi. org/10.3923/je.2011.101.122. 
FINNEY, D.J., 1964. Probit analysis: a statistical treatment of the sigmoid response curve. Cambridge: University Press.

GOETTEL, M.S., EILENBERG, J. and GLARE, T.R. 2005. Entomopathogenic fungi and their role in regulation of insect populations. In: L.I. GILBERT, K. IATROU and S. GILL, eds. Comprehensive Molecular Insect Science. Amsterdam: Elsevier, pp. 361-406. http://dx.doi.org/10.1016/B0-44-451924-6/00088-0.

GONÇALVES, S.G., SILVA, C.A.D., MACÊDO, M.M.F.D. and VASCONCELOS, E.D., 2015. Oviposição do curuquerê e alimentação de suas lagartas neonatas em algodoeiros tratados com caulim. Pesquisa Agropecuária Brasileira, vol. 50, no. 7, pp. 526-533. http://dx.doi.org/10.1590/S0100-204X2015000700002.

GUEDES, V.S., SILVA, C.A.D. and ZANUNCIO, J.C., 2020. Survival, development and reproduction of Phenacoccus solenopsis (Hemiptera: Pseudococcidae) on kaolin-treated cotton. Brazilian Journal of Biology $=$ Revista Brasileira de Biologia. http://dx.doi.org/10.1590/1519-6984.216184. [On line] PMid:31778478.

HAJEK, A., 1997. Ecology of terrestrial fungal entomopathogens. In: I.G. JONES, ed. Advances in Microbial Ecology. New York: Springer, pp. 193-249.

HOCHULI, D.F., 2001. Insect herbivory and ontogeny: how do growth and development influence feeding behaviour, morphology and host use? Austral Ecology, vol. 26, pp. 563-570. https://doi. org/10.1046/j.1442-9993.2001.01135.x.

MASON, C.J. and RAFFA, K.F., 2014. Acquisition and structuring of midgut bacterial communities in gypsy moth (Lepidoptera: Erebidae) larvae. Environmental Entomology, vol. 43, no. 3, pp. 595-604. http://dx.doi.org/10.1603/EN14031. PMid:24780292.

NASCIMENTO, A.R.B., FARIAS, J.R., BERNARDI, D., HORIKOSHI, R.J. and OMOTO, C., 2016. Genetic basis of Spodoptera frugiperda (Lepidoptera: Noctuidae) resistance to the chitin synthesis inhibitor lufenuron. Pest Management Science, vol. 72, no. 4, pp. 810-815. http://dx.doi.org/10.1002/ ps.4057. PMid:26097123.

NEVES, R.C.S., COLARES, F., TORRES, J.B., SANTOS, R.L. and BASTOS, C.S., 2014. Rational practices to manage boll weevils colonization and population growth on family farms in the Semiarid region of Brazil. Insects, vol. 5, no. 4, pp. 818-831. http://dx.doi.org/10.3390/insects5040818. PMid:26462942.

OLIVEIRA, J.R.G., FERREIRA, M.C. and ROMÁN, R.A.A., 2010. Diameter of droplets and different equipments for the application of insecticide to control Pseudoplusia includes. Engenharia Agrícola, vol. 30, no. 1, pp. 92-99. http://dx.doi. org/10.1590/S0100-69162010000100010.

SACKETT, T.E., BUDDLE, C.M. and VINCENT, C., 2005. Effect of kaolin on fitness and behavior of Choristoneura rosaceana (Lepidoptera: Tortricidae) Larvae. Journal of Economic Entomology, vol. 98, no. 5, pp. 1648-1653.

SAMODRA, H. and IBRAHIM, Y., 2006a. Effectiveness of selected entomopathogenic fungi in packed rice grain at room temperature against Corcyra cephalonica Stainton. Asean Journal on Science and Technology for Development, vol. 23, no. 3, pp. 183-192. http://dx.doi.org/10.29037/ajstd.103.

SAMODRA, H. and IBRAHIM, Y., 2006b. Effects of dust formulation of three entomopathogenic fungal strains against Sitophilus oryzae (Coleopteran: Curculionidae) in rice grain. Journal of Biosciences, vol. 17, no. 1, pp. 1-7. PMid:16595869.
SANTORO, P.H., NEVES, P.M.O.J., ALEXANDRE, T.M. and ALVES, L.F.A., 2007. Interferência da metodologia nos resultados de bioensaios de seleção de fungos entomopatogênicos para o controle de insetos. Pesquisa Agropecuária Brasileira, vol. 42, no. 4, pp. 483-489. http://dx.doi.org/10.1590/S0100204X2007000400005.

SARATE, P.J., TAMHANE, V.A., KOTKAR, H.M., RATNAKARAN, N., SUSAN, N., GUPTA, V.S. and GIRI, A.P., 2012. Developmental and digestive flexibilities in the midgut of a polyphagous pest, the cotton bollworm, Helicoverpa armigera. Journal of Insect Science, vol. 12, no. 1, pp. 1-16. http://dx.doi. org/10.1673/031.012.4201. PMid:22954360.

SHOWLER, A.T., 2003. Effects of kaolin particle film on beet armyworm, Spodoptera exigua (Hübner) (Lepidoptera: Noctuidae), oviposition, larval feeding and development on cotton, Gossypium hirsutum L. Agriculture, Ecosystems \& Environment, vol.95, no. 1, pp. 265-271. http://dx.doi.org/10.1016/ S0167-8809(02)00101-9.

SILVA, C.A.D., 2001. Seleção de isolados de Beauveria bassiana patogênicos ao bicudo-do-algodoeiro. Pesquisa Agropecuária Brasileira, vol. 36, no. 2, pp. 243-247. http://dx.doi.org/10.1590/ S0100-204X2001000200005.

SILVA, C.A.D. and RAMALHO, F.S., 2013. Kaolin spraying protects cotton plants against damages by boll weevil Anthonomus grandis Boheman (Coleoptera: curculionidae). Journal of Pest Science, vol. 86, no. 3, pp. 563-569. http://dx.doi.org/10.1007/ s10340-013-0483-0.

SREE, K.S. and VARMA, A. 2015. Biocontrol of Lepidopteran Pests. Switzerland Springer International Publishing. http:// dx.doi.org/10.1007/978-3-319-14499-3

STORM, C., SCOATES, F., NUNN, A., POTIN, O. and DILLON, A., 2016. Improving efficacy of Beauveria bassiana against stored grain beetles with a synergistic co-formulant. Insects, vol. 7, no. 3, pp. 1-14. http://dx.doi.org/10.3390/insects7030042. PMid:27571107.

VAREA, G.S., OLIVEIRA, J.A.Y., SUGAHARA, V.H., ITO, E.T., PINTO, J.P., TREVISAN, D., RAMOS, H.J.O., MAGALHÃES, D.M. and PEREIRA, L.F.P., 2012. Identificação de proteases produzidas pelo fungo entomopatogênico Beauveria bassiana (Bals) Vuill. Cepa CG432 previamente ativada em insetos vivos de broca do café (Hypothenemus hampei). Semina: Ciências Agrárias, vol. 33, no. 2, suppl. 2, pp. 3055-3068. http://dx.doi. org/10.5433/1679-0359.2012v33Supl2p3055.

VIANA, D.D., NETTO, J.C., AGUIRRE-GIL, O.J. and BUSOLI, A.C., 2014. Biological parameters of soybean looper in cotton cultivars with the Cry1 Ac and Cry1F proteins. Pesquisa Agropecuária Brasileira, vol. 49, no. 7, pp. 569-572. http:// dx.doi.org/10.1590/S0100-204X2014000700010.

WRAIGHT, S.P., RAMOS, M.E., AVERY, P.B., JARONSKI, S.T. and VANDENBERG, J.D., 2010. Comparative virulence of Beauveria bassiana strains against lepidopteran pests of vegetable crops. Journal of Invertebrate Pathology, vol. 103, no. 3, pp. 186-199. http://dx.doi.org/10.1016/j.jip.2010.01.001. PMid:20060396.

WROŃSKA, A.K., BOGUS, M.I., WLOKA, E., KAZEK, M., KACZMAREK, A. and ZALEWSKA, K., 2018. Cuticular fatty acids of Galleria mellonella (Lepidoptera) inhibit fungal enzymatic activities of pathogenic Conidiobolus coronatus. PLoS $O N E$, vol. 3, no. 3, pp. e0192715. http://dx.doi.org/10.1371/ journal.pone.0192715. PMid:29518079. 
XUE, J., ZHOU, X., ZHANG, C.-X., YU, L.-L., FAN, H.-W., WANG, Z., XU, H.-J., ZHU, Z.-R., ZHOU, W.-W., PAN, P.-L., LI, B.-L., COLBOURNE, J.K., NODA, H., SUETSUGU, Y., KOBAYASHI, T., ZHENG, Y., LIU, S., ZHANG, R., LIU, Y., LUO, Y.-D., FANG, D.-M., CHEN, Y., ZHAN, D.-L., LV, X.-D., CAI, Y., WANG, Z.B., HUANG, H.-J., CHENG, R.-L., ZHANG, X.-C., LOU, Y.-H., YU, B., ZHUO, J.-C., YE, Y.-X., ZHANG, W.-Q., SHEN, Z.-C., YANG, H.M., WANG, J., WANG, J., BAO, Y.-Y. and CHENG, J.-A., 2014. Genomes of the rice pest brown planthopper and its endosymbionts reveal complex complementary contributions for host adaptation. Genome Biology, vol. 15, no. 12, pp. 1-19. http:// dx.doi.org/10.1186/s13059-014-0521-0. PMid:25609551 .
ZALUCKI, M.P., CLARKE, A.R. and MALCOLM, S.B. 2002. Ecology and behavior of first instar larval Lepidoptera. Annual Review of Entomology, vol. 47, pp. 361-393.

ZHANG, S., WIDEMANN, E., BERNARD, G., LESOT, A., PINOT, F., PEDRINI, N. and KEYHANI, N.O., 2012. CYP52X1, representing new cytochrome $\mathrm{P} 450$ subfamily, displays fatty acid hydroxylase activity and contributes to virulence and growth on insect cuticular substrates in entomopathogenic fungus Beauveria bassiana. The Journal of Biological Chemistry, vol. 287, no. 16, pp. 13477-13486. http://dx.doi.org/10.1074/jbc. M111.338947. PMid:22393051. 